\title{
The investigation of the creative thinking levels and the critical thinking disposition of pre-service elementary teachers
}

Bilge GÖK ${ }^{* *}$
Tolga ERDOĞAN ${ }^{* * *}$

\begin{abstract}
The purpose of the study is to investigate the creative thinking levels and the critical thinking disposition of freshman students at the Division of Elementary Teaching in terms of various variables and to determine whether there is a relationship between the creative thinking levels and the disposition of critical thinking of the students. The study is a descriptive study. In the collection, analysis and interpretation of the data related to the study, quantitative research method was used. The study was carried out with 103 students who were availability of access among the freshman students enrolled in at Hacettepe University Elementary Teaching Division. Torrance Creative Thinking Test was used in order to determine the creative thinking levels; and California Critical Thinking Disposition Inventory was used to determine the critical thinking levels of the students. The data obtained in the study was analyzed using t-test, one-way variance analysis, Kruskal Wallis, Pearson and Spearman Brown correlation coefficient.
\end{abstract}

Keywords: Creative thinking, critical thinking, pre-service teacher of elementary education.

\footnotetext{
* A part of this study was presented in 7th National Elementary Teacher Education Symposium.

Res. Assist., Hacettepe University, Faculty of Education, Ankara, Turkey. E-mail: bilgeb@ hacettepe.edu.tr

${ }^{* * *}$ Res. Assist. Dr., Abant İzzet Baysal University, Faculty of Education, Bolu, Turkey. Email: tolga_edu@hotmail.com
} 


\section{SUMMARY}

Purpose and Significance: In this study, it is aimed at investigating the creative thinking levels and the disposition of critical thinking of freshman students at the Division of Elementary Teaching in terms of various variables and determining whether there is a relationship between the creative thinking levels and the disposition of critical thinking of the students. The related studies indicated that creative thinking levels and critical thinking disposition are influenced with various variables. Determination of the variables which affect students' creative thinking levels and the critical thinking tendency is considerable for the studies and arrangements toward these variables. It is also significant to improve the students' abilities on this manner.

Method: Descriptive model was used in this study. In the collection, analysis and interpretation of the data obtained in this study quantitative research method was used. The study was carried out with 103 students.

Results: The findings of the study indicate that when the creative thinking levels differ in terms of gender, critical thinking disposition of students do not differ in terms of gender. In the study a significant relationship at low level was found between students' creative thinking levels and their academic achievements. Moreover, it was found that there is no relationship between students' critical thinking disposition and academic achievements. There is a significant relationship between students' creative thinking levels and their mothers' educational background whereas there is no significant relationship between the students' critical thinking level and their mothers' educational background. In the study there is no significant relationship between the students' creative thinking levels and critical thinking disposition and their fathers' educational background. It was also found that there is positively significant relationship at medium level between the students' creative thinking levels and critical thinking disposition. Moreover, it was found that there is a positively significant relationship at low level between the sub dimensions of creative thinking test and sub dimensions of critical thinking disposition inventory.

Discussion and Conclusions: As a result, the findings indicate that creative thinking is influenced with the gender, academic achievement, mothers' educational background but it is not influenced with the type of graduated high school, fathers' educational background; critical thinking is not influenced with any of the variables taken into consideration in this study. Besides this, it was supported with the findings of this study that creative and critical thinking are two important high level thinking skills which are interrelated. 


\section{Sınıf Öğretmeni Adaylarının Yaratıcı Düşünme Düzeyleri ve Eleştirel Düşünme Eğilimlerinin İncelenmesi*}

\author{
Bilge GÖK ${ }^{* *}$
}

\author{
Tolga ERDOĞAN ${ }^{* * *}$
}

ÖZ. Bu araştırmanın amacı, Sınıf Öğretmenliği Ana Bilim Dalında okuyan birinci sınıf öğrencilerinin yaratıcı düşünme düzeyleri ile eleştirel düşünme eğilimlerinin çeşitli değişkenler açısından incelenmesi ve öğrencilerin yaratıcı düşünme düzeyleri ile eleștirel düşünme eğilimleri arasında ilişki olup olmadığının belirlenmesidir. Araştırma betimsel nitelik taşımaktadır. Araştırmaya ilişkin verilerin toplanmasında, analizinde ve yorumlanmasında nicel araştırma yöntemi kullanılmıştır. Araştırma, Hacettepe Üniversitesi Sınıf Öğretmenliği Ana Bilim Dalında okuyan birinci sınıf öğrencileri arasından ulaşılabilen toplam 103 öğrenci üzerinde yürütülmüştür. Öğrencilerin yaratıcı düşünme düzeylerini belirlemek amacıyla Torrance Yaratıcı Düşünme Testi, eleştirel düşünme eğilimlerini belirlemek amacıyla da California Eleştirel Düşünme Eğilimi Ölçeği kullanılmıştır. Araştırmada elde edilen veriler $\mathrm{t}$ testi, tek yönlü varyans analizi, Kruskal Wallis Testi, Pearson ve Sperman Brown Korelâsyon Katsayısı yöntemleri kullanılarak analiz edilmiştir.

Anahtar Sözcükler: Yaratıcı düşünme, eleştirel düşünme, sınıf öğretmeni adayı.

\footnotetext{
* Bu araştırmanın bir bölümü VII. Ulusal Sınıf Öğretmenliği Eğitimi Sempozyumu'nda sözlü bildiri olarak sunulmuştur.

Arş. Gör., Hacettepe Üniversitesi, Eğitim Fakültesi, Ankara, Türkiye. E-posta: bilgeb@hacettepe.edu.tr

**** Arş. Gör. Dr., Abant İzzet Baysal Üniversitesi, Eğitim Fakültesi, Bolu, Türkiye. E-posta: tolga_edu@hotmail.com
} 


\section{GíRiș}

Bilgi birikiminin artması ve teknoloji alanındaki hızlı gelişmeler insan yaşamında köklü ve sürekli değişmelere yol açmaktadır. Bu değişime ayak uydurmak ve yaşanan gelişmelerden geri kalmamak tüm toplumların amacı olmuştur. Günümüzde bütün toplumların amac1; araştırmacı, sorgulayıc1, yaratıc1, eleştirici, katılımcı, yeniliklere uyum sağlayan, düşüncelerini uygulamaya dönüştüren, problem çözebilen aktif bireyler yetiştirmektir (Kirişçioğlu, Başdaş ve Başöncül, 2007; Koray ve Çil, 2006).

Çağdaş dünyanın gereksinimleri günümüz bireylerinin düşünme becerilerine sahip olmalarını bir zorunluluk haline getirmiştir. Gelişen teknoloji ile değişen dünyada sadece bilgiye sahip bireylerin çağdaş dünyaya uyum sağlamakta güçlük çekeceği ortaya çıkmaktadır. Günümüzde bireylerin ne kadar çok bilgiye sahip olduğu değil, bilgiye ulaşma sürecinde ne kadar etkin olduğu önem kazanmaktadır. Bunun yanı sıra, giderek artan bilgi birikiminin eğitimle aktarılmasının olanaksızlığı karşısında, bireylerin kendi kendilerine bilgi edinmeleri ve sorunlarını kendilerinin çözmek zorunda kalmaları üst düzey düşünme becerilerinin önemini ortaya koymaktadır (Demirel, 1993; Akt. Aybek, 2006: 38).

Bilgi çağında eleştirel düşünme becerilerini sergileyen, bilgi üreten, sorgulayan, yaratıcı düşünen bireylerin yetiştirilmesi gereklilik haline gelmiştir. Bu durum, eğitimde de yeni beklentilerin ortaya çıkmasına sebep olmuştur. Günümüzde eğitimin en önemli amacı, değişik koşullara uyum sağlayabilecek, farkl1, esnek ve özgün düşünebilecek bireyler yetiştirmektir. Tüm dünyadaki bu genel değişim, eğitim sistemlerini etkilemekte ve eğitim programları gözden geçirilerek çağın gereksinimlerini karşılayacak şekilde geliştirilmektedir (Seferoğlu ve Akbıyık, 2006; Zayif, 2008). Bu kapsamda, eğitim programlarının yetiştirilmek istenen bireylerde bulunmasını öngördüğü yaratıcı ve eleştirel düşünme kavramlarının önemi ortaya çıkmaktadır.

Yaratıcı ve eleştirel düşünme birbiriyle ilişkili iki önemli düşünme becerisidir. Yaratıcı ve eleştirel düşünme araştırmacı, sorgulayıcı düşünme türleridir. Yaratıcı düşünebilen kişiler aynı zamanda olay ya da durumlara eleştirel bakabilen kişilerdir. Yaratıcı düşünme, yeni, özgün ürünler ortaya koymayı, yeni çözümler bulmayı, bir senteze ulaşmayı sağlayan bir düşünce şeklidir. Yaratıcılık, eleştirel bakmak, yeni önermelerde bulunmaktır. Alışılmışın, bilinenin dışında, farklı, yeni, özgün olmak, problemi görmek, farklı çözüm yollarından giderek yeni sonuçlar çıkarmaktır (Emir, 2001: 35; Emir ve Bahar, 2003: 91-110).

Yaratıcı düşünme süreci tüm duyuşsal ve düşünsel etkinliklerde, her türlü çalışmanın ve uğraşın içerisinde vardır. Yaratıcılık hem bir süreç hem 
de bu sürecin sonunda ortaya özgün bir ürün ortaya koyma olarak ele alınabilir (Yenilmez ve Yolcu, 2007). Yaratıcılık; esneklik, çok yönlü düşünme, duyarlılık, çevreye, insanlara karşı uyanık ve ilgili olma, akıcılık, rahat, çabuk ve bağımsız düşünebilme ve hareket edebilme, orijinallik, farklı ve değişik sonuçlara varabilme gibi özellikleri içeren bir süreçtir (Akt. Çakmak, Özdemir ve Çevik, 2007: 395).

Wallas (1926) yaratıcı düşünme sürecinin hazırlık, kuluçka, aydınlanma ve doğrulama olmak üzere dört aşamada gerçekleştiğini belirtmektedir (Emir ve Bahar, 2003: 91-110; Erden ve Akman, 1994: 222; Hilgard ve Atkins, 1967, Akt. Aslan, 1994: 28-29; Özden, 1997: 179-180; San, 1993: 79; Y1ldırım, 1998: 40):

1.Hazırlık Dönemi: Bir soruna bilinçli, sistematik ve mantıksal yaklaşmayı içerir.

2.Kuluçka Dönemi: Hazırlık dönemini takip eder. Bu dönemde bilinç kontrolü bulunmadığından yeni sentezler ve orijinal bazı görüşler ortaya çıkar.

3. Aydınlanma Dönemi: Kişinin bir önceki dönemde elde ettiği bilgiler arasında çeşitli sentezler yaparak çözümü bulduğu dönemdir.

4. Sonuçların Doğrulanması: Bilinçli ve akılcı bir dönemdir. Daha önce bulunan çözümlerin aksaklıkları giderilip, doğrulukları tekrar gözden geçirilir. Bu sürecin sonucunda yaratıcı ürünler ortaya konulabilir.

Yaratıcı düşünme; bireylere yeni, özgün ürünler ortaya koyma, yeni çözümler bulma, bir senteze ulaşma düşüncesi sağlayan bir düşünce şeklidir (Emir, 2001: 35). Yaratıcı düşünmeye katkıda bulunduğu kabul edilen yetenekler vardır. Bu yetenekler, Torrance (1962) tarafından geliştirilen araçlarla ölçülen açıklama (açımlama), akıcılık, esneklik ve orijinallik olarak bilinen yeteneklerdir (Aslan, 1994; Bonk \& Smith, 1998: 261-293; Emir ve Bahar; 2003: 91-110).

a. Açıklama: Yaratıcılık için bir zemin oluşturur, aksi halde yaratıcılık sinırlı kalmaktadır.

b. Akıcılık: Belli bir süre içerisinde çok sayıda kabul edilebilecek düşünce, çözüm veya alternatifler üretmektir.

c. Esneklik: Üretilen düşünce, çözüm veya alternatiflerde çeşitliliktir. Olaylara çok yönlü bakış açısı kazandırmaktır.

d. Özgünlük: Özgünlük veya orijinallik, zihinsel enerji gerektiren bir özelliktir. Ortaya çıkan düşünce yeni ve az rastlanır başka bir deyişle, cevaplar alışılmışın dışında olmalıdır.

Yaratıcı düşünme sürecinde etkili olan ve yaratıcı kişilerden beklenen eleştirel düşünme becerisi ise gerçekleri analiz etme, fikirleri üretip düzenleme, fikirleri savunma, karşılaştırma yapma, çıkarımlar yapma, savları değerlendirme ve problem çözme becerilerinin tümü olarak 
tanımlanmaktadır (Şenkaya, 2005: 28). Eleştirel düşünme becerisinin temel dayanağını bilişsel beceriler (süreçler) oluşturmaktadır. Bunlar; yorum yapma, analiz etme, değerlendirme, çıkarım yapma, açıklama ve öz düzenlemedir (Facione, 1998: 4). Facione (1998: 5)'e göre, eleştirel düşünen kişiler düşündüklerini ve bu yargıya nasıl vardıklarını açılayabilen kişilerdir.

Eleştirel düşünme, özel bir düşünce alanına ya da biçimine ilişkin kusursuz düşünceyi ortaya çıkaran disiplinli ve öz denetimli düşünce biçimidir. Eleştirel düşünmenin bilgiye ulaşmayı ve bilginin yeni durumlarda kullanılmasını temel aldığı söylenebilir (Şahinel, 2005; Zayif, 2008). Eleştirel düşünme, önyargıların, varsayımların, sunulan her türlü bilginin sınandığ 1 ve değerlendirildiği; farklı yönlerinin ve sonuçlarının tartışıldığ 1 ve sonunda bir karara varmayı hedefleyen bir düşünce biçimidir. Eleştirel düşünmenin, üst düzey bilişsel becerileri gerektiren, karmaşık ve kapsamlı bir süreç olduğu söylenebilir (Güven ve Kürüm, 2006).

Eleştirel düşünen bireyler birçok yönden eleştirel düşünmeyen bireylerden farklı düşünür ve davranırlar. $\mathrm{Bu}$ bireylerin en önemli farklılıkları; eleştirel düşünen bireylerin yaşamları boyunca karşılaştıkları her durum veya olayın nedenini anlamaya çalışmaları, bunun altında yatan gerçeklerin neler olabileceğini sorgulamaları, okudukları ve duyduklarının gerçekliği hakkında bilgi edinmeleri, karşılaştıkları problemin üstesinden gelmek için çözümler üretmeye gayret etmeleridir (Özdemir, 2005).

Günümüzde okullardan beklenen en önemli görev, demokratik, yaratıc1, üretici, eleştirel ve çok yönlü düşünebilen, öğrenmeyi öğrenen, problem çözebilen bireyler yetiştirmektir. $\mathrm{Bu}$ niteliklere sahip bireylerin yetiştirilmesinde en önemli kişi öğretmendir. Çağdaş toplumun öğretmeni, sürekli öğrenmeyi bir ilke olarak benimseyen, çok yönlü, demokratik, sorunların üstesinden gelmeyi başaran, yaratıcı ve eleştirel düşünme becerisine sahip olmalıdır (Kuran, 2002). Sönmez (1993)'e göre, öğrenme ve öğretme ortamları öğrencinin yaratıcı ve eleştirel düşünme becerilerini geliştirecek biçimde düzenlenmelidir. Bu bakımdan öğretmen, öğrencilerin çok boyutlu düşünmelerini sağlamak için uygun strateji, yöntem ve teknikleri eğitim ortamında kullanmalıdır.

Çağdaş bir eğitimciden beklenen yaratıcı ve eleştirel düşünce sistematiğinin bireyde geliştirilmesini sağlamaktır. $\mathrm{Bu}$ nedenle, bir eğitimciden öğrencilerini kişilikli bir birey olarak kabul etmesi, onları özgür davranmaya özendirmesi, kendisinin de onlara model olması, sürekli kendini yenileyebilmesi, bildiklerini kendisinden emin ve kolay anlaşılabilen bir biçimde aktarabilmesi ve verdiği bilginin daima amacını vurgulaması beklenir. Eğitimci kendisinin bir kişilik yaratıcısı olduğunu unutmamalıdır (Eriç, 1998: 141). Öğretmenler bireylerin yetiştirilmesinde önemli role sahip 
olduklarından öğrencilerini yaratıcı ve eleştirel düşünen bireyler olarak yetiştirmelidirler. Bunun yanı sıra öğretmenler öğrencilerinin merak duygularını geliştirecek ve problemlere karş1 duyarlılık gösterecek şekilde yetiştirmelerini sağlamalıdırlar.

Öğretmen, bilginin otoriter kaynağı olmak yerine, yaratıcı ve eleştirel düşünmeyi destekleyen ve geliştiren rehber ve yardımcı konumunda olmalıdır. Bu bir anlamda, öğretmenlerin model olarak merak ve tutkuyla yeni bir şeyin üretiminde yer almalarını gerektirmektedir. Burada önemli olan var olan bilginin aktarımı değil, öğrencilerin bilgiyi keşfetmeleri, kendileri için yapılandırmaları ve problemleri çözmek için yönlendirilecek şekilde yetiştirilmeleridir (Cropley, 2004: 168).

Öğretmenlerin öğrencilerdeki yaratıcı ve eleştirel düşünme becerilerini geliştirebilmeleri için her şeyden önce kendilerinin yaratıcı ve eleştirel bir kişiliğe sahip olmaları ve öğrenciler için uygun bir model olmaları gerekmektedir. Yaratıcı ve eleştirel düşünme; rahat, eğlenceli, keyifli, zaman baskısından uzak bir ortamda gerçekleşir. O halde öğretmen, öğrenciler için baskıdan uzak, eğlenceli, rahat bir öğretme-öğrenme ortamı hazırlayabilmelidir. Böyle bir ortamın hazırlanmasında, öğretmen nitelikleri çok büyük önem taşır (Senemoğlu, 1996). Bu nedenle, öğretmenlerin gerek hizmet öncesi gerekse hizmet sırasında, yaratıcı ve eleştirel düşünme becerilerine sahip olacak ve bu becerileri geliştirecek şekilde yetiştirilmeleri gerekmektedir. Öğretmen adaylarının yaratıcı ve eleştirel düşünme becerilerine sahip olmaları bu niteliklere sahip öğrencilerin yetiştirilmesi bakımından önem kazanmaktadır.

$\mathrm{Bu}$ araştırmada, Hacettepe Üniversitesi Sınıf Öğretmenliği Ana Bilim Dalında okuyan birinci sınıf öğrencilerinin yaratıcı düşünme düzeyleri ve eleştirel düşünme eğilimlerinin çeşitli değişkenler açısından incelenmesi ve öğrencilerin yaratıcı düşünme düzeyleri ile eleştirel düşünme eğilimleri arasında ilişki olup olmadığının belirlenmesi amaçlanmıştır. Bu konuda yapılan araştırmalar, öğrencilerin yaratıcı düşünme düzeyleri ve eleştirel düşünme eğilimlerinin çeşitli değişkenlerden etkilendiğini ortaya koymaktadır (Emir, Erdoğan ve Kuyumcu, 2007; Facione ve arkadaşları, 1995; Gönen ve arkadaşları, 1997; Hamurcu, Günay ve Özyılmaz, 2005; Hayran, 2000; Kaloç, 2005; Kökdemir, 2003; Kürüm, 2002; Mangır ve Çağatay, 1991; Olive 1972; Öncü, 1989; Özdemir, 2005; Türkel, 1998; Zayif, 2008). Öğrencilerin yaratıcı düşünme düzeyleri ve eleştirel düşünme eğilimlerini etkileyen değişkenlerin belirlenmesi, ilgili değişkenlere yönelik gerekli çalışma ve düzenlemelerin yapılması ile öğrencilerin bu becerilerinin geliştirilmesi açısından oldukça önemlidir. Bu amaç ve önem kapsamında yapılan araştırmada aşağıdaki sorulara yanıt aranmıştır: 
1. Sınıf Öğretmenliği Ana Bilim Dalı birinci sınıfta okuyan öğrencilerin yaratıcı düşünme düzeyleri ve eleştirel düşünme eğilimleri cinsiyete göre farklılık göstermekte midir?

2. Sınıf Öğretmenliği Ana Bilim Dalı birinci sınıfta okuyan öğrencilerin yaratıcı düşünme düzeyleri ve eleştirel düşünme eğilimleri mezun olunan lise türüne göre farklılık göstermekte midir?

3. Sınıf Öğretmenliği Ana Bilim Dalı birinci sınıfta okuyan öğrencilerin yaratıcı düşünme düzeyleri ve eleştirel düşünme eğilimleri akademik başarıya göre farklılık göstermekte midir?

4. Sınıf Öğretmenliği Ana Bilim Dalı birinci sınıfta okuyan öğrencilerin yaratıcı düşünme düzeyleri ve eleştirel düşünme eğilimleri anne eğitim durumuna göre farkl1lık göstermekte midir?

5. Sınıf Öğretmenliği Ana Bilim Dalı birinci sınıfta okuyan öğrencilerin yaratıcı düşünme düzeyleri ve eleştirel düşünme eğilimleri baba eğitim durumuna göre farkl1lık göstermekte midir?

6. Sınıf Öğretmenliği Ana Bilim Dalı birinci sınıfta okuyan öğrencilerin yaratıcı düşünme düzeyleri ve eleştirel düşünme eğilimleri arasında ilişki var mıdır?

\section{YÖNTEM}

\section{Araştırmanın Modeli}

Sınıf Öğretmenliği Ana Bilim Dalında okuyan birinci sınıf öğrencilerinin yaratıcı düşünme düzeyleri ve eleştirel düşünme eğilimlerinin çeşitli değişkenler açısından incelenmesi ve öğrencilerin yaratıcı düşünme düzeyleri ile eleştirel düşünme eğilimleri arasında ilişki olup olmadığının belirlenmesini amaçlayan bu çalışmada var olan durumu olduğu gibi ortaya koyma amacı güdüldügüünden betimsel model kullanılmıştır. Araştırmada elde edilen verilerin toplanmasında, analizinde ve yorumlanmasında nicel araştırma yöntemi kullanılmıştır.

\section{Evren ve Örneklem}

Araştırmanın evrenini Hacettepe Üniversitesi Eğitim Fakültesi Sınıf Öğretmenliği Ana Bilim Dalı birinci sınıfta okuyan 120 öğrenci oluşturmaktadır. Araştırma, Hacettepe Üniversitesi Sınıf Öğretmenliği Ana Bilim Dalında okuyan birinci sınıf öğrencileri arasından ulaşılabilen toplam 103 öğrenci üzerinde yürütülmüş̧ür. Bununla birlikte bu dönemden önceki ve sonraki dönemlerde Sınıf Öğretmenliği Anabilim Dalındaki öğrenci 
grupları arasında çok büyük bir farklılık olmadıkça, çalışma evreni daha da geniş olarak görülebilir.

\section{Veri Toplama Araçları}

Araştırmada, öğrencilerin yaratıcı düşünme düzeylerini belirlemek amacıyla Torrance Yaratıcı Düşünme Testi'nin (TYDT) sözel bölümü kullanılmıştır. TYDT Türkçeye Yontar (1985) tarafından uyarlanmıştır ve dil eşdeğerliği, güvenirliği ve Türkçeye uyarlanan testin geçerliliği Aslan (1999) tarafindan yapılmıştır. Sözel Yaratıcı Düşünme Testi "soru sorma, nedenleri tahmin etme, sonuçları tahmin etme, ürün geliştirme, alışılmadık kullanımlar, alışılmadık sorular, farz edin ki” olmak üzere 7 etkinlikten oluşmaktadır. TYDT'nin bütününün Cronbach Alfa güvenirlik katsayıs1 .85 olarak hesaplanmıştır. Bu testin değerlendirilmesi TYDT'nin norm ve kriter dayanaklı ölçütlerini kapsayan yönergeler doğrultusunda yapılmıştır. Testte verilen cevapların miktarı akıcılık puanı, cevapların kaç ayrı türde düşünüldüğü esneklik puanı, alışılmadık olması ise orijinallik puanı olarak değerlendirilmektedir. $\mathrm{Bu}$ alt ölçeklerden elde edilen veriler; akıcılık, esneklik ve orijinallik becerilerine göre değerlendirilmiştir. Araştırmada kullanılan TYDT alt boyutları ve toplamına ait Cronbach Alfa güvenirlik katsayıları Tablo 1'de verilmiştir.

Tablo 1. TYDT'ne ilişkin Cronbach Alfa güvenirlik katsayıları

\begin{tabular}{cc}
\hline TYDT & Cronbach Alfa \\
\hline Akıcılık & .73 \\
Esneklik & .89 \\
Orijinallik & .78 \\
Yaratıclik Toplam & .85 \\
\hline
\end{tabular}

Ayrıca araştırmada öğrencilerin eleştirel düşünme eğilimlerini belirlemek amaciyla Facione, Facione ve Giancarlo (1998) tarafindan geliştirilen California Eleştirel Düşünme Eğilimi Ölçeği (The California Critical Thinking Disposition Inventory) kullanılmıştır. Ölçeğin Türkçeye uyarlaması ve Türkiye'deki geçerlik ve güvenirlik çalışması Kökdemir (2003) tarafından yapılmıştır. Eleştirel Düşünme Eğilimi Ölçeği (EDEÖ); analitiklik, açık fikirlilik, meraklılık, kendine güven, doğruyu arama ve sistematiklik olmak üzere toplam 6 boyut ve 51 maddeden oluşmaktadır. Kökdemir (2003) tarafından yapılan çalışmada ölçeğin toplam iç tutarlık katsayısı (alfa) .88; alt boyutlar için ise; analitiklik .75, açık fikirlilik .76, merakl111k .78, kendine güven, .77, doğruyu arama .61, sistematiklik .63 olarak bulunmuştur. Ölçeğin açıkladığı toplam varyans ise \%36.13’tür. 
Eleştirel Düşünme Eğilimi Ölçeği, bir bütün olarak değerlendirildiğinde puan1 240'dan az olan kişilerin genel eleştirel düşünme eğilimleri düşük, 240 ile 300 arasında olanların eleştirel düşünme eğilimleri olumlu yönde, puanı 300 'den fazla olanların ise bu eğilimleri yüksek olarak değerlendirilmektedir. Araştırmada kullanılan eleştirel düşünme eğilimi ölçeği alt boyutları ve toplamına ait Cronbach Alfa güvenirlik katsayıları Tablo 2'de verilmiştir.

Tablo 2. EDEÖ'ne ilişkin Cronbach Alfa güvenirlik katsayıları

\begin{tabular}{cc}
\hline EDEÖ & Cronbach Alfa \\
\hline Analitiklik & .70 \\
Açık Fikirlilik & .71 \\
Meraklılık & .69 \\
Kendine Güven & .71 \\
Doğruyu Arama & .70 \\
Sistematiklik & .68 \\
Eleştirel Toplam & .78 \\
\hline
\end{tabular}

\section{Verilerin Analizi}

Araştırmada, Torrance Yaratıcı Düşünme Testi ve Eleştirel Düşünme Eğilimi Ölçeği'nden elde edilen veriler ile araştırmada ele alınan değişkenler SPSS 11.5 programında t testi, tek yönlü varyans analizi (ANOVA), Kruskal Wallis Testi, Pearson ve Sperman Brown Korelasyon Katsayısı yöntemleri kullanılarak analiz edilmiştir. Bağımlı değişkene ilişkin ölçümlerin dağılımı her iki grupta normal olduğu için öğrencilerin cinsiyete göre yaratıc1 düşünme testi ve eleştirel düşünme eğilimi ölçeğinden aldıkları puanlar arasında anlamlı bir fark olup olmadığına t testiyle bakılmıştır. Öğrencilerin lise türüne göre yaratıcı düşünme testinden aldıkları puanlar arasında anlamlı bir fark olup olmadığı puanlar normal dağılım göstermediğinden ve varyanslar homojen olmadığından dolayı Kruskal Wallis Testi, eleştirel düşünme eğilimi ölçeğinden aldıkları puanlar arasında fark olup olmadığı ise puanlar normal dağılım gösterdiği ve varyanslar homojen olduğu için tek yönlü varyans analizi ile incelenmiştir. Öğrencilerin yaratıcı düşünme testi puanları ile akademik başarıları arasındaki ilişkiye, puanlar normal dağılım göstermediği için Sperman Brown Korelâsyon Katsayısı ile eleştirel düşünme testi ile akademik başarıları arasındaki ilişkiye ise puanlar normal dağılım gösterdiği için Pearson Korelâsyon Katsayısı ile bakılmıştır. Öğrencilerin anne eğitim durumuna göre yaratıcı düşünme testinden aldıkları puanlar arasında fark olup olmadığ 1 Kruskal Wallis Testi ile eleştirel düşünme testinden aldıkları puanlar arasında fark olup olmadığı ise tek 
yönlü varyans analiziyle incelenmiştir. Öğrencilerin baba eğitim durumuna göre yaratıcı ve eleştirel düşünme testinden aldıkları puanlar arasında fark olup olmadığına ise tek yönlü varyans analiziyle bakılmıştır. Ayrıca ögrencilerin yaratıcı düşünme testinde yer alan alt boyutlar ve toplam puanları ile eleştirel düşünme eğilimi ölçeği alt boyutları ve toplam puanları arasındaki ilişki Pearson Korelâsyon Katsayısıyla incelenmiştir.

\section{BULGULAR}

\section{Birinci Alt Probleme İlişkin Bulgular}

Sınıf Öğretmenliği Ana Bilim Dalı birinci sınıfta okuyan öğrencilerin cinsiyete göre yaratıcı düşünme testi ve eleştirel düşünme eğilimi ölçeğinden aldıkları puanlar arasında anlamlı fark olup olmadığına $t$ testi ile bakılmıştır. Ortalamalar arası farkın istatistiksel olarak anlamlı olup olmadığına ilişkin sonuçlar Tablo 3 ve Tablo 4'te verilmiştir.

Tablo 3. Öğrencilerin yaratıcı düşünme testinden aldıkları puanların cinsiyete göre t testi sonuçları

\begin{tabular}{cccll}
\hline Cinsiyet & $\mathrm{n}$ & $\bar{x}$ & \multicolumn{1}{c}{ Ss } & t \\
\hline K1z & 70 & 76.73 & 33 & \\
Erkek & 33 & 65.12 & 23.49 & $2.04^{*}$ \\
\hline
\end{tabular}

$* \mathrm{p}<.05$

Tablo 3'teki veriler incelendiğinde, kız öğrencilerin yaratıcı düşünme testinden aldıkları puanların ortalamasının 76.73, erkek öğrencilerin ise 65.12 olduğu görülmektedir. Buna göre öğrencilerin yaratıcı düşünme testinden aldıkları puanların cinsiyete göre anlamlı bir farklılık gösterdiği ( $\mathrm{t}$ $(85)=2.04, p<.05)$ ve bu farkın kız öğrenciler lehine olduğu ortaya ç1kmaktadır. Bununla birlikte etki büyüklüğü incelendiğinde $\eta^{2}=0.032$ olduğu için cinsiyetin yaratıc1lığa etkisinin pratik olarak anlamlı fakat düşük düzeyde olduğu söylenebilir.

Tablo 4. Öğrencilerin eleştirel düşünme eğilimi ölçeğinden aldıkları puanların cinsiyete göre t testi sonuçları

\begin{tabular}{ccccc}
\hline Cinsiyet & $\mathrm{n}$ & $\bar{x}$ & Ss & $\mathrm{t}$ \\
\hline K1z & 70 & 194.60 & 17.66 & \multirow{2}{*}{0.51} \\
Erkek & 33 & 192.33 & 22.61 & \\
\hline
\end{tabular}


Tablo 4'teki veriler incelendiğinde, kız öğrencilerin eleştirel düşünme eğilimi ölçeğinden aldıkları puanların ortalamasının 194.6, erkek öğrencilerin ise 192.33 olduğu görülmektedir. Buna göre öğrencilerin eleştirel düşünme eğilimi ölçeğinden aldıkları puanlar cinsiyete göre anlamlı bir farkl1l1k göstermemektedir $(\mathrm{t}(51)=0.51, \mathrm{p}>.05)$.

\section{İkinci Alt Probleme İlişkin Bulgular}

Sınıf Öğretmenliği Ana Bilim Dalı birinci sınıfta okuyan öğrencilerin mezun olunan lise türüne göre yaratıcı düşünme testi ve eleştirel düşünme eğilimi ölçeğinden aldıkları puanlar arasında anlamlı bir fark olup olmadığına tek yönlü varyans analizi ile bakılmıştır. Ortalamalar arası farkın istatistiksel olarak anlamlı olup olmadığına ilişkin sonuçlar Tablo 5 ve Tablo 6' da verilmiştir.

Tablo 5. Öğrencilerin yaratıcı düşünme testinden aldıkları puanların mezun olunan lise türüne göre Kruskal Wallis Testi sonuçlart

\begin{tabular}{ccccc}
\hline Mezun olunan lise türü & $\mathrm{n}$ & Sira ortalaması & $\mathrm{sd}$ & $\chi^{2}$ \\
\hline Genel lise & 35 & 47.09 & & \\
Anadolu Lisesi & 18 & 62.64 & & \\
Anadolu öğretmen lisesi & 25 & 53.18 & 3 & 3.38 \\
Diğer & 25 & 50.04 & & \\
Toplam & 103 & & & \\
\hline
\end{tabular}

Tablo 5'teki verilere göre, öğrencilerin yaratıcı düşünme testinden aldıkları puanlar mezun olunan lise türüne göre anlamlı bir farklılık göstermemektedir ( $\mathrm{p}>$.05).

Tablo 6. Öğrencilerin eleştirel düşünme eğilimi ölçeğinden aldıkları puanların lise türüne göre ANOVA sonuçları

\begin{tabular}{crccc}
\hline Varyansın kaynağı & Kareler toplamı & sd & Kareler ortalaması & F \\
\hline Gruplararası & 283.89 & 3 & 94.63 & \\
Gruplariçi & 37707.47 & 99 & 380.88 & 0.25 \\
Toplam & 37991.36 & 102 & & \\
\hline
\end{tabular}

Tablo 6'daki veriler incelendiğinde, öğrencilerin eleştirel düşünme eğilimi ölçeğinden aldıkları puanlar lise türüne göre anlamlı bir farklılık göstermediği görülmektedir ( $\mathrm{p}>.05)$. 


\section{Üçüncü Alt Probleme İliş̧kin Bulgular}

Sınıf Öğretmenliği Ana Bilim Dalı birinci sınıfta okuyan öğrencilerin akademik başarıları ile yaratıcı düşünme testinden aldıkları puanlar arasındaki ilişkiye Sperman Brown Korelâsyon Katsayısıyla, eleştirel düşünme eğilimi ölçeğinden aldıkları puanlar arasında ilişki olup olmadığına ise Pearson Korelâsyon Katsayısıyla bakılmıştır. Bu değişkenle puanlar arasındaki ilişkiye ait sonuçlar Tablo 7 ve Tablo 8'de verilmiştir.

Tablo 7. Öğrencilerin yaratıcı düşünme düzeyleri ile akademik başarıları arasındaki iliş̧kiye ait Sperman Brown Korelâsyon Katsayısı sonuçları

\begin{tabular}{lcrrc}
\hline & $\mathrm{n}$ & $\bar{x}$ & \multicolumn{1}{c}{ Ss } & $\mathrm{r}$ \\
\hline Yaratıcı düşünme & 103 & 73.00 & 30.65 & $0.29 *$ \\
Akademik başarı & 103 & 2.73 & 0.53 & \\
\hline * $<<05$ & & &
\end{tabular}

Tablo 7'deki verilere göre, öğrencilerin yaratıcı düşünme düzeyleri ile akademik başarıları arasında 0.29 düzeyinde bir ilişki bulunmuştur $(p<.05)$. Buna göre öğrencilerin yaratıcı düşünme düzeyleri ile akademik başarıları arasında düşük düzeyde bir ilişki olduğu söylenebilir.

Tablo 8. Öğrencilerin eleştirel düşünme eğilimleri ile akademik başarıları arasındaki ilişkiye ait Pearson Korelâsyon Katsayısı sonuçları

\begin{tabular}{ccrrr}
\hline & $\mathrm{n}$ & $\bar{x}$ & \multicolumn{1}{c}{ Ss } & \multicolumn{1}{c}{$\mathrm{r}$} \\
\hline Eleştirel düşünme & 103 & 193.87 & 19.30 & \multirow{2}{*}{0.11} \\
Akademik başarı & 103 & 5.02 & 1.11 & \\
\hline
\end{tabular}

Tablo 8'deki veriler incelendiğinde, öğrencilerin eleştirel düşünme eğilimleri ile akademik başarıları arasında ilişki olmadığı görülmektedir.

\section{Dördüncü Alt Probleme İlişkin Bulgular}

Sınıf Öğretmenliği Ana Bilim Dalı birinci sınıfta okuyan öğrencilerin anne eğitim durumuna göre yaratıcı düşünme testinden aldıkları puanlar arasında anlamlı bir fark olup olmadığına Kruskal Wallis Testiyle, eleştirel düşünme eğilimi ölçeğinden aldıkları puanlar arasında anlamlı bir fark olup olmadığına ise tek yönlü varyans analizi ile bakılmıştır. Ortalamalar arası farkın istatistiksel olarak anlamlı olup olmadığına ilişkin sonuçlar Tablo 9 ve Tablo 10'da verilmiştir. 
Tablo 9. Öğrencilerin yaratıcı düşünme testinden aldlkları puanların anne eğitim durumuna göre Kruskal Wallis Testi sonuçları

\begin{tabular}{ccccc}
\hline Anne eğitim durumu & $\mathrm{n}$ & Sira ortalaması & sd & $\chi^{2}$ \\
\hline İlköğretim & 76 & 48.89 & & \\
Ortaöğretim & 18 & 52.53 & 2 & $7.19^{*}$ \\
Yükseköğretim & 9 & 77.11 & & \\
\hline${ }^{\mathrm{p}}<.05$ & & &
\end{tabular}

Tablo 9'daki verilere göre, öğrencilerin yaratıcı düşünme testinden aldıkları puanlar anne eğitim durumuna göre anlamlı bir farklılık göstermektedir $(\mathrm{p}<.05)$. Bu bulgu, anne eğitim durumunun yaratıcı düşünme üzerinde farklı etkilere sahip olduğunu gösterir. Grupların sıra ortalamaları dikkate alındığında, annesi yükseköğretim mezunu olan öğrencilerin yaratıcılık testi puanlarının ilköğretim ve ortaöğretim mezunu olanlara oranla daha yüksek olduğu görülmektedir. Bununla birlikte etki büyüklüğü incelendiğinde $\eta^{2}=0.1379$ olduğu için anne eğitim durumunun yaratıc1lığa etkisinin pratik olarak anlamlı ve yüksek düzeyde olduğu söylenebilir.

Tablo 10. Öğrencilerin eleştirel düşünme eğilimi ölçeğinden aldıkları puanların anne ĕgitim durumuna göre ANOVA sonuçları

\begin{tabular}{ccccc}
\hline Varyansın kaynağı & Kareler toplamı & sd & Kareler ortalaması & F \\
\hline Gruplararası & 772.583 & 2 & 386.29 & \\
Gruplariçi & 37218.78 & 100 & 372.19 & 1.04 \\
Toplam & 37991.36 & 102 & & \\
\hline
\end{tabular}

Tablo 10'daki veriler incelendiğinde, öğrencilerin eleştirel düşünme eğilimi ölçeğinden aldıkları puanlar anne eğitim durumuna göre anlamlı bir farklılık göstermemektedir ( $\mathrm{p}>.05)$.

\section{Beşinci Alt Probleme İlişkin Bulgular}

Sınıf Öğretmenliği Ana Bilim Dalı birinci sınıfta okuyan öğrencilerin baba eğitim durumuna göre yaratıcı düşünme testi ve eleştirel düşünme eğilimi ölçeğinden aldıkları puanlar arasında anlamlı bir fark olup olmadığına tek yönlü varyans analizi ile bakılmıştır. Ortalamalar arası farkın istatistiksel olarak anlamlı olup olmadığına ilişkin sonuçlar Tablo 11 ve Tablo 12'de verilmiştir. 
Tablo 11. Öğrencilerin yaratıcı düşünme testinden aldıkları puanların baba eğitim durumuna göre ANOVA sonuçlarl

\begin{tabular}{ccccc}
\hline Varyansın kaynağ & Kareler toplamı & sd & Kareler ortalaması & F \\
\hline Gruplararası & 465.99 & 2 & 232.99 & \\
Gruplariçi & 953.77 & 100 & 953.77 & 0.24 \\
Toplam & 95842.99 & 102 & & \\
\hline
\end{tabular}

Tablo 11'deki verilere göre, öğrencilerin yaratıcı düşünme testinden aldıkları puanlar baba eğitim durumuna göre anlamlı bir farklılık göstermemektedir $(\mathrm{p}>.05)$.

Tablo 12. Öğrencilerin eleştirel düşünme eğilimi ölçeğinden aldılklart puanların baba eğitim durumuna göre ANOVA sonuçları

\begin{tabular}{ccccc}
\hline Varyansın kaynağı & Kareler toplamı & sd & Kareler ortalaması & F \\
\hline Gruplararası & 1545.54 & 2 & 772.77 & \\
Gruplariçi & 36445.82 & 100 & 364.46 & 2.12 \\
Toplam & 37991.36 & 102 & & \\
\hline
\end{tabular}

Tablo 12'deki verilere göre, öğrencilerin eleştirel düşünme eğilimi ölçeğinden aldıkları puanlar baba eğitim durumuna göre anlamlı bir farklılık göstermemektedir ( $\mathrm{p}>.05)$.

\section{Altıncı Alt Probleme İlişkin Bulgular}

Öğrencilerin yaratıcı düşünme testinde yer alan alt boyutlar ve toplam puanları ile eleştirel düşünme eğilimi ölçeği alt boyutları ve toplam puanları arasındaki ilişki Pearson Korelâsyon Katsayısı ile incelenmiş ve sonuçlar Tablo 13'te verilmiştir.

Tablo 13'teki veriler incelendiğinde, yaratıcı düşünme testi toplam puanı ile eleştirel düşünme eğilimleri ölçeği toplam puanı arasında orta düzeyde, pozitif yönde anlamlı bir ilişki olduğu görülmektedir $(r=0.34$, $\mathrm{p}<.05$ ). Buna göre yaratıcı ve eleştirel düşünme toplam puanları arasında pozitif bir ilişkinin bulunması, yaratıcı düşünme düzeyi puanlarının artması durumunda eleştirel düşünme eğilimi puanlarının da arttı̆̆ şeklinde yorumlanabilir. Determinasyon katsayısı $\left(\mathrm{r}^{2}=0.12\right)$ dikkate alındığında, eleştirel düşünme eğilimlerindeki toplam varyansın (değişkenliğin) \%12'sinin yaratıcı düşünme düzeylerinden kaynaklandığı söylenebilir. Ancak teorik olarak açıklanan varyans diğer değişken için de yorumlanabilir. 
Ayrıca eleştirel düşünme eğilimi ölçeği alt boyutları arasında yer alan meraklılık ile yaratıcı düşünme testi alt boyutlarının tümü (akıcılık, esneklik, orijinallik) ve yaratıcı düşünme testi toplam puanı arasında düşük düzeyde, pozitif yönde anlamlı bir ilişki vardır. Eleştirel düşünme eğilimi ölçeğinin kendine güven alt boyutu ile yaratıcı düşünme testi akıcılık, orijinallik ve yaratıcılık toplam puanları arasında düşük düzeyde, pozitif yönde anlamlı bir ilişki; doğruyu arama ve sistematiklik ile akıcılık, esneklik, orijinallik ve yaratıcılık toplam arasında düşük düzeyde, pozitif yönde anlamlı bir ilişki olduğu görülmüsstür.

Tablo 13. Öğrencilerin yaratıcı düşünme düzeyleri ve eleştirel düşünme eğilimleri arasındaki ilişkiye ait Pearson Korelâsyon Katsayısı sonuçları

\begin{tabular}{|c|c|c|c|c|c|c|c|c|c|c|c|}
\hline Değișkenler & 1 & 2 & 3 & 4 & 5 & 6 & 7 & 8 & 9 & 10 & 11 \\
\hline \multicolumn{12}{|l|}{ 1. Akıcılık } \\
\hline $\mathrm{r}$ & 1.00 & & & & & & & & & & \\
\hline \multicolumn{12}{|l|}{$\mathrm{p}$} \\
\hline \multicolumn{12}{|l|}{ 2. Esneklik } \\
\hline $\mathrm{r}$ & .86 & 1.00 & & & & & & & & & \\
\hline $\mathrm{p}$ & .00 & .00 & & & & & & & & & \\
\hline \multicolumn{12}{|l|}{ 3. Orijinal } \\
\hline $\mathrm{r}$ & .97 & .89 & .94 & 1.00 & & & & & & & \\
\hline $\mathrm{p}$ & .00 & .00 & & & & & & & & & \\
\hline \multicolumn{12}{|l|}{ 4. Yaratıcılık Toplam } \\
\hline $\mathrm{r}$ & .97 & .89 & .94 & 1.00 & & & & & & & \\
\hline $\mathrm{p}$ & .00 & .00 & .00 & & & & & & & & \\
\hline \multicolumn{12}{|l|}{ 5. Analitiklik } \\
\hline $\mathrm{r}$ & .158 & .19 & .06 & .13 & 1.00 & & & & & & \\
\hline $\mathrm{p}$ & .14 & .05 & .55 & .20 & & & & & & & \\
\hline \multicolumn{12}{|l|}{ 6. Açık Fikirlilik } \\
\hline $\mathrm{r}$ & .04 & .03 & -.04 & .01 & .38 & 1.00 & & & & & \\
\hline $\mathrm{p}$ & .72 & .79 & .72 & .93 & .00 & & & & & & \\
\hline \multicolumn{12}{|l|}{ 7. Meraklılık } \\
\hline $\mathrm{r}$ & .27 & .22 & .22 & .26 & .22 & .15 & 1.00 & & & & \\
\hline $\mathrm{p}$ & .00 & .02 & .02 & .00 & .02 & .12 & & & & & \\
\hline \multicolumn{12}{|l|}{ 8. Kendine Güven } \\
\hline $\mathrm{r}$ & .24 & .19 & .22 & .24 & .29 & .19 & .46 & 1.00 & & & \\
\hline $\mathrm{p}$ & .01 & .06 & .02 & .00 & .00 & .05 & .00 & & & & \\
\hline \multicolumn{12}{|l|}{ 9. Doğruyu Arama } \\
\hline $\mathrm{r}$ & .21 & .23 & .20 & .22 & .14 & .08 & .20 & .35 & 1.00 & & \\
\hline $\mathrm{p}$ & .03 & .02 & .04 & .02 & .15 & .39 & .04 & .00 & & & \\
\hline \multicolumn{12}{|l|}{ 10. Sistematiklik } \\
\hline $\mathrm{r}$ & .30 & .24 & .24 & .29 & .35 & .20 & ,32 & .60 & .20 & 1.00 & \\
\hline $\mathrm{p}$ & .00 & .01 & .01 & .00 & .00 & .04 & .00 & .00 & .04 & & \\
\hline \multicolumn{12}{|l|}{ 11. Elesstirel Düș. Top. } \\
\hline $\mathrm{r}$ & .35 & .33 & .29 & .34 & .55 & .30 & .62 & .80 & .52 & .67 & 1.00 \\
\hline $\mathrm{p}$ & .00 & .00 & .00 & .00 & .00 & .00 & .00 & .00 & .00 & .00 & \\
\hline
\end{tabular}




\section{TARTIŞMA VE SONUÇ}

$\mathrm{Bu}$ araştırmada, Sınıf Öğretmenliği Ana Bilim Dalı birinci sınıfta okuyan öğrencilerin yaratıcı düşünme düzeyleri ve eleştirel düşünme eğilimlerinin çeşitli değişkenler açısından incelenmesi ve öğrencilerin yaratıcı düşünme düzeyleri ve eleştirel düşünme eğilimleri arasında ilişki olup olmadığının belirlenmesi amaçlanmıştır. Araştırmada elde edilen sonuçlar, öğrencilerin yaratıcı düşünme düzeylerinin cinsiyete göre anlamlı bir farklılık gösterdiğini ortaya koymaktadır. Kız ve erkek öğrenciler aynı eğitim sürecinden geçmelerine rağmen, kız öğrencilerin erkek öğrencilere göre yaratıcı düşünmeyi geliştiren etkinliklere daha çok ilgi duydukları ve bu tür etkinliklerin kız öğrencilerin yapısına daha uygun olduğu söylenebilir. Ayrıca kız öğrenciler aile ve yakın çevresindeki kişiler tarafından bu tür etkinliklere daha çok yönlendirilmektedir. Belirtilen bu nedenler, araştırmada elde edilen kız öğrencilerin erkek öğrencilere göre yaratıcı düşünme düzeylerinin daha yüksek olduğu sonucunu desteklemektedir. Araştırmadan elde edilen bu sonuç doğrultusunda erkek öğrencilerin yaratıcı düşünme becerilerini geliştirmeleri için gerekli eğitim ortamlarının sağlanması ve öğrencilerin bu konuda yönlendirilmesi gerektiği söylenebilir. Araştırmanın bu sonucu Emir, Erdoğan ve Kuyumcu (2007) ve Öncü (1989) tarafından yapılan ve yaratıcı düşünme ile cinsiyet arasındaki ilişkiyi inceleyen çalışmalarla paralellik gösterirken, Gönen ve arkadaşları (1997) ve Mangır ve Çağatay (1991) tarafından yapılan çalışmalarla paralellik göstermemektedir.

Ayrıca araştırmada öğrencilerin eleştirel düşünme eğilimlerinin cinsiyete göre anlamlı bir farklılık göstermediği sonucuna ulaşılmıştır. Kız ve erkek öğrencilerin aynı eğitim sürecinden geçmeleri ve bu süreçte gerek aile gerekse öğretmenler tarafından eleştirel düşünme becerisini geliştirmeye yönelik yeterli yönlendirmelerin yapılmaması ve bu tür çalışmalara ilköğretimden başlayarak yükseköğretime kadar devam eden eğitim sürecinde yeterince yer verilmemesi bu becerinin cinsiyete göre farkl1l1k göstermemesini etkileyen nedenler arasında gösterilebilir. Araştırmanın bu bulgusu, Kaloç (2005) ve Özdemir (2005) tarafindan yapılan ve eleştirel düşünmeyle cinsiyet arasındaki ilişkiyi inceleyen çalışmayla tutarlılık gösterirken, Facione ve arkadaşları (1995), Hamurcu, Günay ve Özyılmaz (2005), Hayran (2000), Kökdemir (2003) ve Zayif (2008) tarafından yapılan çalışmalarla tutarlılık göstermemektedir.

Araştırmada öğrencilerin yaratıcı düşünme düzeyleri ve eleştirel düşünme eğilimleri mezun oldukları lise türüne göre farkl1l1k göstermemektedir. Türkiye'de çeşitli lise türlerinde farklı öğretim programları uygulanmaktadır. Bu lise türlerinde eğitim gören öğrencilerin 
yaratıcı ve eleştirel düşünme becerilerinin farkl1lık göstermesi beklenen bir durumdur. Buna rağmen araştırmada elde edilen sonuç, öğrencilerin yaratıcı ve eleştirel düşünme becerilerinde mezun oldukları lise türünün herhangi bir etkisinin olmadığını ortaya koymaktadır. Bu kapsamda, farklı lise türlerinde öğrencilere verilen eğitimin öğrencilerin üst düzey düşünme becerilerini geliştirecek şekilde düzenlenmesi gerektiği söylenebilir. Böylece farklı liselerde verilen eğitim süreci, öğrencilerin yaratıcı ve eleştirel düşünme becerilerini geliştirme düzeyi açısından gözden geçirilmelidir.

Araştırmada elde edilen bu bulgu, Zayif (2008) tarafından yapılan ve öğrencilerin eleştirel düşünme eğilimleri ile mezun olunan lise türü arasındaki ilişkiyi inceleyen çalışma ile paralellik gösterirken, Kürüm (2002) tarafindan yapılan çalışmayla paralellik göstermemektedir.

Araştırmada ögrencilerin yaratıcı düşünme düzeyleri ile akademik başarıları arasında düşük düzeyde anlamlı bir ilişki bulunmuştur. Araştırmanın bu bulgusu, Sınıf Öğretmenliği Ana Bilim Dalı birinci sınıftaki öğrencilerin derslerindeki akademik başarılarıla ilgili yapılan değerlendirmelerin yaratıcı düşünme becerilerine yeteri kadar yönelik olmadığını ortaya koymaktadır. Bu doğrultuda, yapılan değerlendirmelerin öğrencilerin yaratıcı düşünme düzeylerine yönelik olacak şekilde düzenlenmesi gerektiği söylenebilir. Araştırmada elde edilen bu bulgu Emir, Erdoğan ve Kuyumcu (2007), Olive (1972) ve Türkel (1998) tarafindan yapılan ve yaratıcı düşünmeyle akademik başarı arasındaki ilişkiyi inceleyen çalışmalarla tutarlılık göstermektedir.

Ayrıca araştırmada öğrencilerin eleştirel düşünme eğilimleri ile akademik başarıları arasında ilişki olmadığı sonucuna ulaşılmıştır. Araştırmada elde edilen bu bulgu, Sınıf Öğretmenliği Ana Bilim Dalı birinci sınıfta okuyan öğrencilerle ilgili yapılan değerlendirmelerin öğrencilerin eleştirel düşünme becerilerine yönelik olmadığını ortaya koymaktadır. $\mathrm{Bu}$ açıdan bakıldığında, değerlendirmelerin öğrencilerin eleştirel düşünme becerilerine yönelik ve bu becerilerini kullanmalarını sağlayacak nitelikte olması gerektiği söylenebilir. Araştırmada elde edilen bu bulgu, Zayif (2008) tarafindan yapılan çalışmayla tutarlılık göstermektedir.

Araştırmada öğrencilerin yaratıcı düşünme düzeyleri ile anne eğitim durumları arasında anlamlı bir ilişki olduğu sonucuna ulaşılmıştır. Bireyin yetiştirilmesinde annenin rolü oldukça önemlidir. Bu süreçte birey, annesiyle babasına göre daha fazla zaman geçirmektedir. $\mathrm{Bu}$ yüzden annenin eğitim durumu bireyin bilişsel ve duyuşsal özellikleri kazanmasında oldukça etkilidir. Anne eğitim durumu yüksek olan öğrencilerin yaratıcı düşünme düzeylerinin yüksek olması beklenmektedir. Araştırmada elde edilen bu sonuç, anne eğitim durumunun öğrencilerin yaratıcı düşünme düzeylerini belirlemede etkili olduğunu göstermektedir. Araştırmanın bu bulgusu, Emir, 
Erdoğan ve Kuyumcu (2007) ve Mangır ve Çağatay (1991) tarafindan yapılan ve yaratıcı düşünme düzeyi ile anne eğitim durumu arasındaki ilişkiyi inceleyen çalışmalarla tutarlılık göstermektedir. Ayrıca araştırmada öğrencilerin eleştirel düşünme eğilimleri ile anne eğitim durumları arasında anlamlı bir ilişki olmadığı sonucuna ulaşılmıştır. Araştırmanın bu bulgusu, öğrencilerin eleştirel düşünme eğilimlerini belirlemede anne eğitim durumunun önemli olmadığını ortaya koymaktadır. Anne eğitim durumuna göre öğrencilerin eleştirel düşünme eğilimlerinin farklılaşmaması, eğitim durumu yüksek olan annelerin de çocuklarını eleştirel düşünme becerilerini geliştirme konusunda yeterli bir şekilde yönlendiremedikleri ve bu konuda onlara gerekli desteği veremedikleri şeklinde yorumlanabilir. Araştırmadan elde edilen bu sonuca göre, aileler bireyleri yetiştirme sürecinde onların yaratıcı ve eleştirel düşünme becerilerini nasıl geliştirebilecekleri ve bu konuda onlara nasıl destek olacakları konusunda bilinçlendirilmelidir. Araştırmada elde edilen bu sonuç, Özdemir (2005) tarafından yapılan çalışmayla tutarlılık göstermektedir.

Araştırmada öğrencilerin yaratıcı düşünme düzeyleri ve eleştirel düşünme eğilimleri ile baba eğitim durumları arasında anlamlı bir ilişki olmadığı sonucuna ulaşılmıştır. Bireylerin yetiştirilmesinde baba önemli bir faktör olmasına rağmen anne kadar bireyle zaman geçirememekte ve yeteri kadar ilgilenememektedir. Bu durum, baba eğitim durumunun öğrencilerin yaratıcı ve eleştirel düşünme becerilerini geliştirmede etkili olmadığ şeklinde yorumlanabilir. Araştırmanın bu bulgusu Emir, Erdoğan ve Kuyumcu (2007) tarafından yapılan ve yaratıcı düşünme düzeyi ile baba eğitim durumu arasındaki ilişkiyi inceleyen çalışmayla, Özdemir (2005) tarafindan yapılan ve eleştirel düşünme eğilimi ile baba eğitim durumu arasındaki ilişkiyi inceleyen çalışmayla tutarlılık göstermektedir.

Araştırmada öğrencilerin yaratıcı düşünme düzeyleri ile eleştirel düşünme eğilimleri arasında orta düzeyde, pozitif yönde anlamlı bir ilişki olduğu ortaya çıkmıştır. Buna göre yaratıcı düşünme düzeyi ile eleştirel düşünme eğilimi arasında pozitif bir ilişkinin bulunması, yaratıcı düşünme düzeyi puanlarının artması durumunda eleştirel düşünme eğilimi puanlarının da arttığ 1 şeklinde yorumlanabilir. Ayrıca araştırmada yaratıcı düşünme testi alt boyutları ile eleştirel düşünme eğilimi ölçeği alt boyutları arasında düşük düzeyde pozitif yönde anlamlı bir ilişki bulunmuştur.

Sonuç olarak araştırmada elde edilen bulgular yaratıcı düşünmenin cinsiyet, akademik başarı, anne eğitim durumu değişkenlerinden etkilendiğini, mezun olunan lise türü, baba eğitim durumu değişkenlerinden etkilenmediğini; eleştirel düşünmenin ise araştırmada ele alınan değişkenlerin hiçbirisinden etkilenmediğini ortaya koymaktadır. Bununla birlikte yaratıcı ve eleştirel düşünmenin birbirleriyle ilişkili iki önemli üst 
düzey düşünme becerisi olduğu bu araştırmanın sonucuyla da desteklenmektedir. Araştımadan elde edilen bu sonuç, öğretmen eğitiminde oluşturulacak eğitim ortamlarının ve derslerde yapılacak değerlendirmelerin öğrencilerin yaratıcı ve eleştirel düşünme becerilerini geliştirecek nitelikte olması gerektiğini ortaya çıkarmaktadır.

Bu araştırma Sınıf Öğretmenliği Ana Bilim Dalı birinci sınıf öğrencileri üzerinde yapılmıştır. Benzer çalışmalar daha geniş örneklem grubu üzerinde ve farklı branşlardaki ögrretmen adayları üzerinde ve ögrretmen adaylarının yaratıcı ve eleştirel düşünme becerilerini etkileyecek farklı değişkenler ele alınarak yapılabilir. Ayrıca bu araştırma öğretmen adayları üzerinde yapılmıştır. Öğretmenlerin de yaratıcı ve eleştirel düşünme becerileri ve bu becerilerini etkileyen değişkenlerini inceleyen araştırmalar yapılabilir.

\section{KAYNAKLAR}

Aslan, A. E. (1994). "Yaratıcı Düşünce Yeteneğine Sahip Ergenlerin Danışmanlığa İhtiyaç Duydukları Problem Alanları Üzerine Bir Araştırma." Yayımlanmamış yüksek lisans tezi, Marmara Üniversitesi, Sosyal Bilimler Enstitüsü, İstanbul.

Aslan, E. (1999). Turkish version of Torrance Test of creative thinking. International Conference on Test Adaptation Proceedings, Georgetown University, Washington D. C., USA.

Aybek, B. (2006). "Konu ve Beceri Temelli Eleştirel Düşünme Öğretiminin Öğretmen Adaylarının Eleştirel Düşünme Eğilimi ve Düzeyine Etkisi." Doktora tezi, Çukurova Üniversitesi, Sosyal Bilimler Enstitüsü, Adana.

Bonk, J. C. \& Smith, G. S. (1998). Alternative instructional strategies for creative and critical thinking in accounting curriculum. Journal of Accounting Education, 16 (2), 261-293.

Cropley, J. A. (2004). Creativity in education \& learning. London: Routledge Falmer.

Çakmak, A., Özdemir, S. M. ve Çevik, E. (2007). Drama eğitiminin sınıf öğretmenliği öğrencilerinin yaratıcılıkları üzerine etkisi. VI. Ulusal Sınıf Ögretmenliği Sempozyumu bildiri kitabı içinde (s. 395-399). Ankara: Nobel Yayın Dağıtım.

Emir, S. (2001). "Sosyal Bilgiler Öğretiminde Yaratıcı Düşünmenin Erişiye ve Kalıcılığa Etkisi." Yayınlanmamış doktora tezi, Hacettepe Üniversitesi, Sosyal Bilimler Enstitüsü, Ankara.

Emir, S. ve Bahar, M. (2003). Yaratıc1lıkla İlgili Öğretmen ve Öğrenci Görüşleri. Abant İzzet Baysal Üniversitesi Sosyal Bilimler Enstitüsü Dergisi, 1 (1). 
Emir, S., Erdoğan, T. ve Kuyumcu, A. (2006). Türkçe Öğretmenliği Öğrencilerinin Yaratıcı Düşünme Düzeyleri ile Sosyo-Kültürel Özelliklerinin İlişkisi. İstanbul Üniversitesi Hasan Ali Yücel Eğitim Fakültesi Dergisi, 4 (1), 73-87.

Erden, M. ve Akman, Y. (1994). Ĕgitim psikolojisi: Geliş̧im, Öğrenme ve Öğretme. Ankara: Arkadaş Yayınevi.

Eriç, M. (1998). Kültür ve Yaratıcılık. İstanbul: Kazancı Yayınları.

Facione, P. A. (1998). Critical thinking: What it is and why it counts. California Academic Press, 8, 1-16.

Facione, P. A., Giancarlo, C. A., Facione, N. C. \& Gainen, J. (1995). The disposition toward critical thinking. Journal of General Education. 44 (1), $1-25$.

Gönen, M., Uzmen, S., Akçin, N. ve Özdemir, N. (1987). Anaokuluna Giden 5-6 Yaş Çocuklarında Yaratıcı Düşünmenin İncelenmesi. Eğitim ve Bilim Dergisi, 65, 64-67.

Güven, M. ve Kürüm, D. (2006). Öğrenme Stilleri ve Eleştirel Düşünme Arasındaki İlişkiye Genel Bir Bakış. Anadolu Üniversitesi Sosyal Bilimler Dergisi, 6 (1), 75-89.

Hamurcu, H., Günay, Y. ve Akamca Özyllmaz G. (2005). Fen Bilgisi ve Sınıf Öğretmenliği Anabilim Dalı Öğrencilerinin Eleştirel Düşünme Eğilimi Profilleri. Eğitim Araştırmaları Dergisi, 20, 147-157.

Hayran, İ. (2000). İlköğretim Öğretmenlerinin Düşünme Beceri ve İşlemlerine İlişkin Görüşleri." Yayımlanmamış yüksek lisans tezi, Afyon Kocatepe Üniversitesi, Sosyal Bilimler Enstitüsü, Afyon.

Kaloç, R. (2005). "Orta Öğretim Kurumu Öğrencilerinin Eleştirel Düşünme Becerileri ve Eleştirel Düşünme Becerilerini Etkileyen Etmenler.” Yayımlanmamış yüksek lisans tezi, Gazi Üniversitesi, Eğitim Bilimleri Enstitüsü, Ankara.

Kirişçioğlu, S., Başdaş, E. ve Başöncül, N. (2007). Eğitim fakültesi'nde öğrenim gören 1. ve 4. sinıf öğrencilerinin eleştirel düşünme eğilimlerinin incelenmesi. E. Erginer (Ed.), 16. Ulusal Eğitim Bilimleri Kongresi bildiri kitabı içinde (c. 2, s. 430-436). Ankara: Detay Yayıncilık.

Koray, Ö. ve Çil, H. (2006). Öğretmen adaylarının öğrenme stilleri ve eleştirel düşünme becerileri arasindaki ilişsinin incelenmesi. $X V$. Ulusal Eğitim Bilimleri Kongresi'nde sunulmuş bildiri, Muğla.

Kökdemir, D. (2003). "Belirsizlik Durumlarında Karar Verme ve Problem Çözme." Yayımlanmamış doktora tezi, Ankara Üniversitesi, Sosyal Bilimler Enstitüsü, Ankara.

Kuran, K. (2002). Öğretmenlik Mesleği (Niteliği ve Özellikleri), A. Türkoğlu (Ed.). Öğretmenlik Mesleğine Giriş. Ankara: İnci Ofset. 
Kürüm, D. (2002). "Öğretmen Adaylarının Eleştirel Düşünme Gücü.” Yayımlanmamış yüksek lisans tezi, Anadolu Üniversitesi, Eğitim Bilimleri Enstitüsü, Eskişehir.

Mangır, M. O. ve Çağatay, N. A. (1991). Alt ve Üst Sosyo-Ekonomik Düzeydeki Dokuz Yaş Çocuklarının Etkileyen Bazı Faktörlerin İncelenmesi. Eğitim ve Bilim Dergisi, 79 (15), 10-19.

Olive, H. (1972). The relation of divergent thinking to intelligence social class, and achievement in high-school studies. The Journal of Genetic Psychology. 121, 179-186.

Öncü, T. (1989). “Torrance Yaratıcı Düşünme Testleri ve Wartegg-Biedma Testi Aracılığıyla 7-11 Yaş Çocuklarının Yaratıcılı̆̆ Yapıları Arasındaki İlişkinin İncelenmesi." Yayınlanmamış doktora tezi, Ankara Üniversitesi, Sosyal Bilimler Enstitüsü, Ankara.

Özcan, A. O. (2000). Algıdan Yoruma Yaratıcı Düşünme. İstanbul: Avcıol Basım Yayın.

Özdemir, S. M. (2005). Üniversite Öğrencilerinin Eleştirel Düşünme Becerilerinin Çeşitli Değişkenler Açısından Değerlendirilmesi. Türk Ĕ̈itim Bilimleri Dergisi, 3 (3).

Özden, Y. (1997). Öğrenme ve Ögrretme. Ankara: PegemA Yayınları.

San, İ. (1993). Sanatta Yaratıcllı (Oyun-Drama), Yaratıcılık ve Eğitim. Ankara: Türk Eğitim Derneği Yayınları.

Seferoğlu, S. S. ve Akbıyık, C. (2006). Eleştirel Düşünme ve Öğretimi. Hacettepe Üniversitesi Eğitim Fakültesi Dergisi, 30, 193-200.

Senemoğlu, N. (1996). Yaratıcılık ve ögretmen nitelikleri. Yaratıcılık ve Eğitim Paneli. Ankara: Kara Harp Okulu, [Online]: http://yunus.hacettepe.edu.tr/ n.senem/makaleler/yaratici.htm adresinden 21 Mart 2008 tarihinde indirilmiștir.

Sönmez, V. (1993). Yaratıcı Okul, Öğretmen, Öğrenci, A. Ataman (Ed.) Yaratıcılık ve eğitim. XVII. Eğitim Toplantısı, Ankara: Türk Eğitim Derneği Yayınları.

Şahinel, S. (2005). Eleştirel Düşünme, Ö. Demirel (Ed.) Eğitimde Yeni Yönelimler. Ankara: PegemA Yayıncılık.

Şenkaya, E. (2005). "Yabancı Dil Yazma Öğretiminde Eleştirel Düşünme Becerilerinin Kullanımının Başarıya Etkisi." Yayımlanmamış yüksek lisans tezi, Hacettepe Üniversitesi, Sosyal Bilimler Enstitüsü, Ankara.

Türkel, A. (1998). "Yüksek Öğretim Türk Dili Derslerinin Yaratıcı ve Bilimsel Düşünme Açısından Değerlendirilmesi." Yayınlanmamıș Yüksek Lisans Tezi, Abant İzzet Baysal Üniversitesi, Sosyal Bilimler Enstitüsü, Bolu. 
Yenilmez, K. ve Yolcu, B. (2007). Öğretmen Davranışlarının Yaratıcı Düşünme Becerilerinin Gelişimine Katkısı. Kırgızistan-Türkiye Manas Üniversitesi Sosyal Bilimler Dergisi, 18, 95-105.

Yildırım, R. (1998). Yaratıcılık ve Yenilik. İstanbul: Sistem Yayıncılık.

Yontar, A. A. (1985). "The effects of method and sex on science achievement logical thinking ability and creative thinking ability of 5th grade students." Yayınlanmamış yüksek lisans tezi, Middle East Technical University, Ankara.

Zayif, K. (2008). "Öğretmen Adaylarının Eleştirel Düşünme Eğilimleri.” Yayımlanmamış yüksek lisans tezi, Abant İzzet Baysal Üniversitesi, Sosyal Bilimler Enstitüsü, Bolu. 
